\title{
БИБЛИОГРАФИЈА КАО ОГЛЕДАЛО ТРАНСКУЛТУРАЛНОСТИ
}

\section{Сажетак}

Текућа национална библиографија представља издавачку продукцију једне земље, укључујући и њене националне мањине. На овај начин библиографија представља огледало више култура и надилази етноцентричне оквире, осликава национална, политичка, верска, географска, лингвистичка, културна превирања и прожимања. У раду ће, на основу анализе српске текуће библиографије, бити представљено које и у којој мери су националне мањине заступљене у текућој националној библиографији.

Кључне речи: библиографија, транскултуралност, мањине, идентитет

\section{Увод}

Текућа национална библиографија постајепредмет интересовања у 17. веку ${ }^{1}$, најпре захваљујући ентузијазму појединаца, да би се крајем 19. и почеткм 20. века развијала под окриљем државних институција. У нашој земљи безмало два века је протекло од смесица и објављивања вести о актуелним издањима до институционилизованог бављења библиографијом². Резултат организованог бележења савремене на-

1 Зачетке текуће националне библиографије представља Bibliographia Parisina у којој је ученик Габријела Нодеа, Луј Жакоб де Сент Шарл, пописао париска издања за период 1643-1648, потом и Bibliographia Gallica universalis која обухвата књиге штампане у Француској од 1643. до 1653. године. (Александра Вранеш, Основи теорије и историје библиографије (Бањалука: Народна и универзитетска библиотека Републике Српске; Београд: Филолошки факултет, 2010), 96).

2 Поред истакнутих појединаца и установе попут Друштва српске словесности, Српског ученог друштва и Срспке краљевске академије допринеле су попису нове издавачке продукције. Ипак, званично бављење библиографијм на националном нивоу почиње са Југословенским библиографско-информацијским институтом (1950-2002), а од 2003. године тај задатак преузима Народна библиотека Србије. 


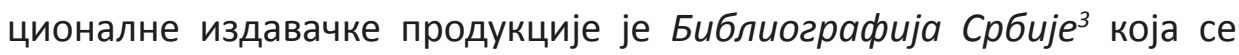
израђује de visu на основу обавезног примерка Народне библиотеке Србије и Библиотеке Матице српске. Принципи на којима почива национална библиграфија, установљени од старне Когресне библиотеке још 1902. године, и данас важе: књиге штампане и издате у једној земљи; књиге аутора који су у њој рођени и ту живе; књиге странаца писане језиком те земље и књиге којима је та земља предмет интересовања. Поштујући територијални принцип Библиографијом Србије је обухваћено и издаваштво националних мањина, те на тај начин она представља огледало више култура и надилази етноцентричне оквире.

\section{Мултикултуралност, интеркултуралност, транскултуралност}

Појмови мултикултурално и интеркултурално се последњих деценија често користе, те се намеће и питање њихове дефиниције, до које се не може доћи ван оквира друштва и заједница уопште. Важно је разликовати ова два појма, јер они никако не значе исто или слично. С једне стране, у мултикултуралној заједници живимо једни поред других, а за развој колективног и индивидуалног идентитета не смеју да постоје препереке за постојеће разлике, што би могло да имплицира да је то заправо коегзистенција различитих култура, што не подразумева нужно и комуникацију и интеракцију међу њима. Ако за неко друштво кажемо да је мултикултурално то не мора да значи и да је интеркултурално. Да би мултикултурално друштво било и интеркултурално требало би да постоји и однос између култура. Интеркултуралност означава могућност поређења различитих мишљења, идеја и култура на једном простору.

Под мултикултурализмом се обично подразумева концепт друштва у којем равноправно коегзистира више култура, а под интеркултурализмом она друштва у којима је више култура у фази дијалога, интеракције и трагања за новом културном синтезом, која представљају дубљи однос међу културама. То нас доводи до појма транскултурал-

3 https://www.nb.rs/pages/article.php?id=7379 (приступљено 28.8.2017) 
ности, термина који се заправо супротставља идеји мултикултуралности и истиче поновно проналажење културног идентитета, међусобно сусретање народа и упознавање различитих култура.

Сталне миграције условљене слободним кретањем становништва у 21. веку довеле су до повећања културног диверзитета у многим државама. Мултикултурализам је таква културна политика која омогућава да у једном друштву живе и развијају се различите културе, како културе мањинских тако и културе већинских група, где су међусобна толеранција и једнакост загарантовани. Као последица све веће миграције становништва, фокус савремених друштава је све више на проблематици која из тога произилази. Како је сама практична ситуација изузетно комплексна и сензитивна, тако је и теорија која је прати широка и представља, још увек, непотпуно истражен интердисциплинарни терен.

„Србија је, због специфичног географског положаја, историјског наслеђа, политичких околности, демографског развитка и сталних миграција становништва, мултиетничка, мултиконфесионална и мултикултурална држава“". Положај мањина у Републици Србији данас уређују Устав усвојен 2006. године и посебни закони међу којима се издвајају Закон о заштити права и слобода националних мањина (2002, наставио је да важи на територији Србије након одвајања Црне Горе од Савезне републике Југославије), Закон о службеној употреби језика и писма, Закон о основама система образовања и васпитања и Закон о локалној самоуправи (2002/6/7). Сем тога, Србија има билатералне уговоре о заштити мањина са Хрватском, Македонијом, Мађарском и Румунијом.

За очување, развој и ширење својих националних култура, националне мањине су добиле посебно право доношењем Закона о националним саветима националних мањина, којим се предвиђа посебна улога Националних савета у смислу представљања националних мањина у области образовања, културе, обавештавања на језику националне мањине и службене употребе језика и писма. ${ }^{5}$

4 Јован Цвијић, Балканско полуострво и јужнословенске земље (Београд: Завод за издавање уџбеника, 1996)

5 „Закон о националним саветима националних мањина“. Сл.гласник РС бр. 72/2009, 20/2014 - одлука УС і 55/2014. 
Према овом Закону, Национални савети имају право да оснивају јавна гласила на језику националне мањине у циљу обавештавања.

\section{Публикације на језицима мањина објављене у Србији}

Према попису становништва из 2011. године и расположивим подацима на сајту Владе Републике Србије у „Србији постоји 21 етничка заједница чија бројност прелази две хиљаде припадника“6. Значајан проценат чине Мађари, Румуни, Роми и Словаци. У којој мери су ове националне мањине заступљене у текућој националној библиографији? Колико се у Србији објављују монографске, односно серијске публикације на језицима мањина? Каква је издавачка продукција намењена националним мањинама? Како би се добили одговори на ова питања, анализиран је период од десет година, 20072017, поштујући територијални принципи (публикације на језицима мањина објављене у Србији). Такође, приказани су наслови који на овим просторима имају континуитет у излажењу. Резултати се приказани у табелама 1 и 4 за монографске и табелама 2 и 3 за серијске публикације.

Табела 1: Монографске публикације на језицима мањина за период 2007-2017

\begin{tabular}{|l|l|}
\hline Језик & Број монографских публикација \\
\hline мађарски & 1964 \\
\hline словачки & 561 \\
\hline румунски & 479 \\
\hline ромски & 131 \\
\hline
\end{tabular}

Како према актуелним статистичким подацима у Србији највећи део мањина чине Мађари (253.899) очекивано је да највише публикација има на мађарском језику. Иако је знатно више Словака од Румуна (52.750 Словака и 29.332 Румуна), тај однос, када је реч

6 http://www.srbija.gov.rs/pages/article.php?id=41 (приступљено 28.8.2017) 
о издаваштву, није тако драстичан. Најмање је публикација на ромском језику и то у великој мери чини поезија.

Серијске публикације представљају изузетно важан чинилац у афирмацији културе, стваралаштва, нових идеја, књижевности, науке и хуманистичких наука, као и у образовању и васпитавању младих и имају посебан значај за интелектуални живот локалних средина у којима се објављују. Објављивање и штампање серијских публикација (новина и часописа) на језицима националних мањина може се подвести под право на службену употребу матерњег језика. У Србији, али највише у Војводини, објављује се велики број наслова серијских публикација на језицима националних мањина и опет се може закључити да је највећи број наслова на мађарском језику, затим на румунском, хрватском, русинском и словачком језику. У табели 2 приказан је број новопокренутих наслова серијских публикација на језицима најбројнијих националних мањина у Србији.

Табела 2: Серијске публикације на језицима мањина покренутим у периоду 2007-2017

\begin{tabular}{|l|l|}
\hline Језик & $\begin{array}{c}\text { Број наслова новопокренутих серијских } \\
\text { публикација у периоду 2007-2017 }\end{array}$ \\
\hline мађарски & 64 \\
\hline хрватски & 19 \\
\hline румунски & 15 \\
\hline русински & 8 \\
\hline словачки & 5 \\
\hline
\end{tabular}

Услед политичких, историјских и културних дешавања на овим просторима постоји богата издавачка делатност на различитим језицима која се осликава у каталозима библиотека. Заједничка одлика првих серијских гласила је да нису била дугог века и често су мењала место излажења. У нашим библиотекама углавном су некомплетна годишта ових наслова. Комплет листа Pancsova és vidéke који је доносио текстове на румунском и немачком језику може се наћи у библиотеци „Сечењи“ у Будимпешти, јер је лист субвенционисала 
мађарска влада. Од анализираних језика националних мањина, најмлађе су серијске публикације на ромском и, попут монографских публикација, најмањи је број наслова на овом језику. Најчешће се објављују двојезично: ромско-српски (као што су најстарије ромске новине у Србији - Циганске новине, односно Romano lil) или вишејезично: ромско-срспко-енглески.

Указаћемо и на значај серијских публикација са традицијом (табела 4), попут дневног листа покренутог 1945. године на мађарском језику Magyar Szó, затим недељника Hét Nap (излази од 1946. године) и Családi kör: független hetilap (излази од 1990. године). Ту је и недељник за децу Jó Pajtás: magyar nyelvü gyermeklap (излази непрекидно од 1947. године), познати часопис за омладину Képes Ifjúság: a jugoszláviai magyar fiatalok hetilapja (1966-2012) и месечник за децу Mézeskalács: legkisebbjeink képes folyóirata, који у издању новосадског издавача Форум непрекидно излази од 1955. године до данас. Часописи на словачком језику су Nový život: časopis pre literatúru a kultúru (излази у Новом Саду у континуитету од 1949. године до данас) и недељник Hlas ludu: organ zhromaždenia AP Vojvodiny pre Slovakov (излази недељно од 1944. године). Часописи за децу и омладину на румунском језику Bucuria copiilor (излази месечно у Панчеву од 1946. године) и Tinereţea: revistă a tinerilor din Voivodina - Republica Serbia (излази месечно од 1995. године). Највећи број издавача серијских публикација на језицима националних мањина има седиште у војвођанским градовима: Новом Саду, Суботици, Сенти, Бачком Петровцу и Панчеву. Неки од најзначајнијих издавача су Libertatea из Панчева, Руске слово из Новог Сада и Култура из Бачког Петровца. Када је реч о серијским публикацијама на ромском језику, можемо издвојити часописе: Alav e Rromengo (излазио месечно од 1994. до 1999. у издању Друштва Војводине за језик и књижевност Рома), часопис Them (излазио двонедељно од 2003. до 2009), часопис Dekada Roma и AP Vojvodini: mesečnik Kancelarije za inkluziju Roma (излази месечно од 2011. године). 
ТРАНСКУЛТУРАЛНОСТ И БИБЛИОТЕКЕ

Табела 3: Серијске публикације на језицима

националних мањина са најдужим континуитетом у излажењу

\begin{tabular}{|l|l|}
\hline \multicolumn{2}{|c|}{ На мађарском језику } \\
\hline Наслов & Почетна година излажења \\
\hline Magyar Szó: a vajdasági népfront napilapja & $1945-$ \\
\hline $\begin{array}{l}\text { Jó Pajtás: magyar nyelvú gyermeklap (до 1957. } \\
\text { године излазиле под насловом Pionirújság) }\end{array}$ & $1947-$ \\
\hline Létünk: társadalom, tudomány, kultúra & $1971-$ \\
\hline \multicolumn{2}{|c|}{ На словачком језику } \\
\hline Наслов & Почетна година излажења \\
\hline $\begin{array}{l}\text { Нlas ĺudu : organ zhromaždenia АР Vojvodiny } \\
\text { pre Slovako }\end{array}$ & $1944-$ \\
\hline Nový život: časopis pre literatúru а kultúru & $1949-$ \\
\hline \multicolumn{2}{|c|}{ На румунском језику } \\
\hline Наслов & Почетна година излажења \\
\hline $\begin{array}{l}\text { Bucuria copiilor (покренут под насловом: } \\
\text { Bucuria pionierilor) }\end{array}$ & $1946-$ \\
\hline Lumina: revistǎ de literară & $1947-$ \\
\hline
\end{tabular}

Да бисмо сагледали колико је националним мањинама доступна српска књига на њиховом језику, анализирали смо и преводилачку делатност (табела 4).

\section{Табела 4: Превођење са српског језика на језике} националних мањина у периоду 2007-2017

\begin{tabular}{|l|l|}
\hline Превођење са српског језика на: & Број монографских публикација \\
\hline мађарски & 270 \\
\hline словачки & 82 \\
\hline румунски & 66 \\
\hline ромски & 12 \\
\hline
\end{tabular}

Подаци из табеле 5 потврђујуда је у Србији замањине најбројније издаваштво на мађарском језику, а најмање је и превођено на ромски језик. Од дванаест преведених књига само три су искључиво на ромском, док су остале публикације вишејезичне. 


\section{Закључак}

Мултикултурализам представља основ данашње локалне заједнице или глобаног савременог друштва чији главни мото треба да буде прихватање, очување и поштовање различитих култура и језика као основ за заједнички живот свих народа. Различите културе коегзистирају у мултиетничким државама, али нису увек и свима приступачне, због језичке баријере, због религијских предубеђења, или социјалних разграничења. Веома често границе међу културама су замућене и неодређене, чему доприносе и миграције становништва. Управо је библиографија, како текућа тако и ретроспективна, вид доказа постојања једне нације и њеног прожимања са другим народима у времену и простору.

Библиографија као наука почива на национално-језичкоисторијско-географским принципима и на тај начин осликава национална, политичка, верска, географска, лингвистичка и културна превирања. Овим истраживањем настојало се да се прикаже заступљеност националних мањина у библиографији, односно да се потврди ширина коју текућа Библиографија Србије има и која може бити средство културолошке пропаганде. Лујза Малклес је на Међународној конференцији библиографа у Варшави 1957. године изнела став да библиографија предствља „културно богатство једне нације и везе те нације са другим народима", што управо и чини основу српске текуће библиографије. ${ }^{7}$

\section{Литература и извори}

Вранеш,Александра.Основитеорије и историјебиблиографије. Бањалука: Народна и универзитетска библиотека Републике Српске; Београд: Филолошки факултет, 2010.

7 Смиља Мишић, „Међународна конференција библиографа у Варшави и питање дефиниције појма национална библиографија“, Библиотекар год. 9, бр. 3-4 (1957): 177 
Мишић, Смиља. „Међународна конференција библиографа у Варшави и питање дефиниције појма национална библиографија“,. Библиотекар год. 9, бр. 3-4 (1957): 175-179

„Закон о националним саветима националних мањина“. Сл. гласник РС бр. 72/2009, 20/2014 - одлука УС и 55/2014

Цвијић, Јован. Балканско полуострво и јужнословенске земље. Београд: Завод за издавање уџбеника, 1996.

http://www.srbija.gov.rs/pages/article.php?id=41 (приступљено 28.8.2017)

https://www.nb.rs/pages/article.php?id=7379 (приступљено 28.8.2017)

\section{Dragana Grujić \\ Gordana Đoković \\ University of Belgrade \\ Faculty of Philology}

\section{BIBLIOGRAPHY AS A MIRROR OF TRANSCULTURALITY}

\section{Summary}

A current national bibliography represents the publishing production of a country, including its national minorities. In this way, bibliography is a mirror of several cultures and transcends ethnocentric frameworks, reflect the national, political, religious, geographical, linguistic, cultural turmoil and permeation. The paper, based on analysis of Serbian current bibliography, will present national minorities and to what extent they are represented in the current national bibliography.

Key words: bibliography, transculturality, minority, identity 